\title{
PUBLIC REASON AND PUBLIC POLICY: THE NEED FOR EPISTEMIC REALISM IN POLITICAL
}

\section{ARGUMENT}

By

James D. Rinn

B.A. 2012 (York University), M.A. 2014 (University of Waterloo)

\author{
An MRP \\ Presented to Ryerson University \\ In partial fulfillment of the \\ Requirements for the degree of \\ Master of Arts \\ In the program of \\ Public Policy and Administration \\ Toronto, Ontario, Canada, 2019 \\ (C) James D. Rinn, 2019
}




\section{AUTHOR'S DECLARATION FOR ELECTRONIC SUBMISSION OF A MRP}

I hereby declare that I am the sole author of this MRP. This is a true copy of the MRP, including any required final revisions. I authorize Ryerson University to lend this MRP to other institutions or individuals for the purpose of scholarly research. I further authorize Ryerson University to reproduce this MRP by photocopying or by other means, in total or in part, at the request of other institutions or individuals for the purpose of scholarly research. I understand that my MRP may be made electronically available to the public. 
Abstract: Public Reason and Public Policy: The Need for Epistemic Realism in Political Argument

Public Policy and Administration

James Duncan Rinn

Master of Arts

Ryerson University

2019

This paper examines the concept of public reason, the regime of principles and rules under which political argument in a liberal-democratic society should be conducted. It examines the two most prominent accounts of public reason: John Rawls', which derives rules of public reason from a presumed duty of mutual respect, and Jurgen Habermas', which begins with the premise that communication is a necessary condition for knowledge. It then answers subjectivist objections to public reason, and concludes that public reason is ultimately defined and upheld by a shared commitment to epistemic realism: the understanding that we inhabit a shared world made up of mind-independent objects that can be known by all members of that shared world. The paper then examines the Canadian citizenry's willingness and capacity to engage in public reason and the government's ability to facilitate it, and concludes that in the absence of political will or a pre-existing culture of public reason, the burden of promoting and sustaining it will fall to organized and motivated sub-sectors of civil society.

Keywords: Public Reason, Public Policy, Rawls, Habermas, Political Knowledge, Civil Society 


\section{$\underline{\text { Table of Contents }}$}

Author's Declaration:

Abstract:

Introduction:

p. 1

Part 1: The Need for Public Reason and the Case for Common-Sense Realism:

p. 1

1.1: The Inevitability of Public Reason:

p. 5

1.2: Why Make Rules for Public Reason:

p. 6

1.3: The Anti-Realist Challenge, and its Answer:

p. 12

1.4: Can Mere Humans be Public Reasoners:

p. 20

1.5: Necessary and Sufficient Conditions for Public Reason:

p. 26

Part 2: The State of Public Reason in Canada:

p. 29

2.1: Absence of Subjectivism:

p. 29

2.2: Intellectual Interest and Competence:

p. 42

Part 3: Policy Options:

p. 47

3.1 The Limited Role of the State:

p. 47 
Conclusion:

p. 58

Reference List:

p. 59 


\section{$\underline{\text { Introduction }}$}

The Oxford Dictionary declared "post-truth" 2016's word of the year (Wang 2016); it denoted "circumstances in which objective facts are less influential in shaping public opinion than appeals to emotion and personal belief" (Lexico, 2019). The President-Elect of the United States would subsequently make 492 "false or misleading claims" within 100 days of taking office (Washington Post, 2017). The rebirth and political success of irrationalist, tribal populist movements in the United States and Europe, reignited debates about the role of reason itself (however defined) in politics. Defenders of political rationality linked the anti-rationalism of the alt-right to the postmodern left's rehabilitation of mysticism and "local" knowledge (Fluss and Landon, 2019), while its critics claimed that "arrogant" belief in absolute truth discovered through science, had alienated citizens from their governments and created the conditions for populist revolt (Jasanoff and Simmet, 2017). This debate over a threat to liberal democracy has thus turned into an argument about the most basic features of political knowledge: what can humans know about the political world? How can or should they try to gain that knowledge? What should they do with it? The question of political knowledge, in turn, leads back to a decades-old debate over the concepts of public reason and communicative rationality: respectively, the claims that citizens should confine their political arguments to terms and content which do not invalidate their peers' reasonable philosophies, and that humans can only arrive at defensible truth claims by communication and mutual critique with other rational persons. These two philosophical projects combine to address the moral and epistemological problems in creating realistic and effective standards for political argument, a necessary 
precondition for effective democratic government, meaning they provide the two sets of necessary conditions any rule of public reason has to meet.

The most basic rule of public discourse that meets both these challenges, as the rest of this paper will demonstrate, is that political speakers must base their arguments on commonsense realism and only accept arguments that do so. This is a collection of simple propositions: objects exist in the world independent of the mind (Stanford Encyclopedia of Philosophy 2014), humans can know the properties of these objects to a meaningful degree and that some ways of doing so are demonstrably better than others. Political knowledge, among all other forms, depends on this along with any form of knowledge addressing aspects of the world outside an observer's mind; common-sense realism is therefore a prerequisite for public reason and communicative rationality, and public policy to ensure the use of public reason must therefore ensure general acceptance of common-sense realism in public discourse before it can address any other issue.

This paper begins with an account of the two principle philosophical approaches to rules of political argument: John Rawls' account of public reason and Jurgen Habermas' of communicative rationality. Rawls' account derives from a pre-existing ethical assumption that rational beings have a duty to respect each other's deeply held beliefs; rational people can espouse conflicting all-encompassing ideologies which are nonetheless reasonable, so to rely solely on one's own in political judgments is to unjustly deny another person's right to selfdetermination through reason (Rawls, 2005). Habermas' approach starts with the problem of knowledge rather than a moral first principle; humans do not have access to self-evident axioms that provide knowledge of the world, nor can they directly access all potentially relevant 
knowledge of the political world, so knowledge in general and political knowledge in particular must be obtained through communication and shared evaluation of experiences and thoughts between persons (Fultner (ed.) 2011). Both accounts require common standards of discourse, and working rules of public reason have to address both the ethical and the epistemological problem. They must also answer skeptical challenges to the possibility of public reason, in particular the argument that knowledge claims cannot be generalized beyond their sociocultural origin. This section will address these criteria, and demonstrate that commonsense realism is necessary in order to meet the criterion of mutual respect (by providing a point of consensus that does not require the exclusion of rational citizens), solve the epistemological problem (by making citizens' knowledge claims intelligible and evaluable to each other by providing a shared frame of reference), and to answer the skeptical challenge to public reason. This paper's second section, evaluates the Canadian citizenry's commitment to common-sense realism in the political arena, and finds several potential threats. Some forms of religion weaken public reason by merging mysticism- belief in supernatural things not seen or proven, by definition beyond the reach of shared experience or evaluation and therefore incompatible with public reason- with political beliefs, in particular as political quietism (for privately-chosen spiritual doctrines), and religious proscriptions on private life (most notably in the case of conservative monotheisms' attitude toward sexual behaviour and cultural production). Epistemic relativism and one of its subsets, standpoint epistemology, poses a distinct but similar threat by according respect and credibility to arguments from personal experience and belief that cannot be evaluated by citizens who do not already share them. Various forms of these theories have become dominant in academic epistemology over the last 
twenty-five years, only recently being challenged by common-sense realism (De Caro 2015).

This spills over into politically-oriented social science research and popular discourse. The final basic problem is self-education; Canadian citizens' willingness and ability to find out basic relevant facts about the world is uneven, with relatively high enthusiasm but a low general knowledge level. This combination of factors, suggests that the preconditions for public reason exist and it can be encouraged through policy, but that substantial obstacles make this a major policy problem.

The final section examines policy possibilities for three major potential sources of public reasoning: the state, non-governmental organizations seeking to strengthen civil society, and the citizens themselves. Governments have a natural tendency to avoid embarrassment through the control of information, so the state cannot realistically be expected to provide information on the internal workings of government or on the consequences of policy choices when this would cause a loss of face; its role would therefore be generally educational, helping to instill a shared approach to political knowledge via the education system. Civil society organizations are likely to perform a similar educational role, their principle advantage over the state being greater practical freedom to directly criticize the actions of both governments and of influential voting blocs, prominent figures or interest groups that a government might try to avoid antagonizing. Individual citizens can also play a key role in educating themselves and others, since public reason rests more on cultivated habits of mind among the citizenry than on material institutional support. 


\section{Part 1: The Need for Public Reason and the Case for Common-Sense Realism}

\section{1: The Inevitability of Public Reason.}

"Public reason", before taking moral or epistemic problems into account, refers to a basic process unavoidable in a democracy. John Rawls began discussion of its purpose and limits by observing that some form of public reason, is an unavoidable feature of a society ruled by a democratic government: "in a democratic society, public reason is the reason of equal citizens who, as a collective body, exercise final political and coercive power over one another in enacting laws and amending their constitution" (Rawls 2005, p. 54). These are very basic conditions for the existence of public reason: the government of a given polity governs with some effectiveness (can enforce at least some decisions about policy and basic constitutional arrangements), has some level of public control (an "authoritarian or aristocratic government" that made decisions without popular input, would not qualify as using public reason (Rawls 2005), and citizens must have at least some freedom to voice their opinions on political topics. Public reason will therefore play a major role in the political life of any country with an elected government and some constitutional framework for political decisions. This set of countries includes both robust democracies and countries still developing elected governments, freedom of speech and effective constitutions. Most countries will therefore use some form of public reason to influence decisions; a stronger state means greater policy capacity and therefore a greater potential to control the use of common resources and coerce citizens, which in turn means a correspondingly larger role for public reason provided the state is not a pure autocracy. 
The obvious policy implication of this fact, is that Canada's elected parliamentary form of government and constitutional guarantee of freedom of expression, ensure that public reason will exist in Canada in some form and will likely have some influence on governments' behaviour and, by extension, on the rights and welfare of Canadian citizens. This in turn raises the question: what (if anything) the government or major civil society actors should do about it? Any answer to this question must explain why participation in political argument would necessarily entail moral obligations, and also whether any morally justifiable set of rules could reasonably be followed by a critical mass of rational citizens.

\section{2: Why Make Rules for Public Reason?}

A common form of public reason requires a combined ethical and practical justification, one that both explains why citizens ought to hold each other to the same standard of political argument, and justifies the consequences of doing so. Rawls and Habermas offer competing justifications for their programs of public reason and communicative rationality, respectively, but Rawls' justification comes with built-in assumptions which fail by his own criteria for political reasonability. Habermas' account of communicative ethics avoids this problem by beginning with the need to justify political knowledge claims, of which moral claims are a subset. The moral and practical justification for public reason ultimately rests on the limits of individual knowledge and the consequent need for communication. Public reason is justified not because it can appeal to a preconceived set of moral rules or assumed description of citizens' shared social world, but because it is the precondition for such knowledge to come into being in the first place. 
Rawls' moral argument for strict limits on acceptable forms of public reason, assumes that citizens have a moral duty of mutual respect and uses said duty as the basis for rules governing political knowledge claims. This limits the scope of public reason while minimizing its rigour. The initial justification for a constrained form of public reason, principally addressing basic constitutional rules and interpretation of law and limited to using commonly accepted arguments, comes from a presumed duty of respect. Reasonableness, in this account, does not automatically lead to a single moral and/or political doctrine which is obviously superior to all others. A reasonable citizen can instead adopt any one of a number of reasonable "comprehensive doctrines" to determine their moral beliefs (Rawls 2005). Reasonable people of any religion or ideology must nonetheless accept the duty of mutual respect; this form of equality should be self-evident to a reasonable agent (Rawls 2005) because a social system that benefits rational agents, cannot survive unless its members respect each other's basic rights within it. This means that reasonable citizens cannot impose their own comprehensive doctrines on political discourse without violating their moral duties (Rawls 2005). Comprehensive doctrines include more than just religious beliefs. Secular doctrines could be plausible to their believers and yet rely on evidence- such as direct experience of some secular version of revelation, of which "local knowledge" deemed inaccessible outside a specific identity group would provide an example- that cannot be evaluated or accepted by reasonable citizens with different ideas based on shareable evidence (Rosenbaum 2009). Nor does disrespect for fellow citizens' comprehensive doctrines require state repression. A political decision based on a comprehensive doctrine, even if that doctrine was implemented due to non-coercive deliberation, would still be in principle unacceptable to adherents of competing 
doctrines who are then coerced by the state (Rawls 2005). Political reason in Rawls' account must therefore be "freestanding": basic principles of justice cannot come from any pre-existing moral theory that may conflict with a reasonable doctrine, and political discourse should only include claims and evidence that can be accepted regardless of one's comprehensive doctrine (Rawls 2005). Rawls cites court decisions as an example of the use of public reason, since judges apply a common method of justification and evaluation (interpretation of statutes and precedent) they have to agree to in order to hold their office, but the requirements of public reason bind regular citizens and politicians as well as judges (Rawls 2005). Public reason therefore has to be universal (acceptable to any reasonable person, regardless of moral or empirical system of thought) yet tolerant (not excluding any school of thought that meets a minimum standard of reasonableness). These conflicting demands make Rawlsian public reason untenable.

Rawls' restrictive notion of public reason shows itself both impractical and selfcontradictory, and in the process shows that a justifiable regime of public reason must deal with the problem of justifying political knowledge claims before it can move on to ethics. Rawls' freestanding notion of public reason has to rely solely on political justifications and explicitly disavows any metaphysical ones (Rawls 2005). This excludes foundationalist arguments for public reason: anything drawing on a first principle outside a society's existing arrangements, such as a metaphysical account of the nature of man from which the public reasoner deduces individual rights and duties, or a moral theory based on natural law, derived from the existence of a just deity (Hedrick 2010). The political justification is supposed to come from an "overlapping consensus": the various comprehensive doctrines that coexist in a given society, 
will agree on basic principles of justice and therefore can find common ground in political debates regardless of other fundamental differences of moral or empirical belief (Rawls 2005). Competing comprehensive doctrines can be reasonable despite disagreement, so avoiding a clash between respectable but mutually exclusive doctrines requires that every political reasoner restrict themselves to arguments that do not trigger such a conflict with another reasonable doctrine. This unavoidable issue of "reasonable disagreement" combines with the notion of overlapping consensus to produce public reason (Hedrick 2010). This is a questionbegging claim, for a comprehensive doctrine may outright reject fairness as the defining feature of justice without contradicting itself or resorting to self-evidently wrong axioms. Rawlsian public reason must then either exclude it as by definition an unreasonable doctrine (for violating the duty of mutual respect), rendering overlapping consensus irrelevant to public reason (Zoffini 2012), or accept as reasonable a doctrine that rejects the key tenets of public reason. It also means that, even if the duty of mutual respect is taken as given, public reason cannot guarantee it given the potential presence of arguments that deny it (Hedrick 2010) (there is no guarantee that a given society's overlapping consensus will include any concept of fairness).

The final problem comes from the requirement for freestanding justification: if public reason cannot be justified by principles outside itself, why require public reason in the first place? Rawls himself had to appeal to pre-existing ideas of justice to give a reason for accepting an overlapping consensus, which ran into the self-contradiction problem mentioned above. The lack of explicit moral grounds for public reason also blurs the line between judgment and description, as the rules of public reason can be seen as just a description of political argument 
in a liberal-democratic state such as the United States which takes the existing set of comprehensive doctrines for granted (Hedrick 2010). This leaves no explanation for change in doctrines and political argument or any help in accommodating it. Public reason might be open to change despite its reliance on consensus if the intellectual work of changing ideologies happens off-stage in the private associations that make up civil society (Flanders 2012), but this renders public reason a by-product of reasons generated by comprehensive doctrines, rather than a meaningful influence of political reasoning. This defeats the purpose of public reason, namely to constrain and channel political argument to bring it into accord with the principle of fairness. The freestanding justification for public reason therefore does not justify it, and neither does the possibility of multiple reasonable, but mutually exclusive comprehensive doctrines. A defensible form of public reason must therefore have a prior justification not created from the process of public reason. The weakness of overlapping consensus as an argument, frees public reason from the moral requirement to integrate conflicts between doctrines into its restrictions.

The problems with Rawlsian public reason mentioned above, derive from its inability to address the problem of political knowledge. The difficulty in evaluating doctrines that reject the duty of respect, becomes inevitable if public reason cannot provide a justification for said duty. This problem of justification in turn follows naturally from the requirement for freestanding justification. If premises about the nature of reasonability and the content of reasonable belief have to be taken as given before offering justifications for public reason, then any such justification becomes a tautology in which public reason is justified according to the principles of public reason i.e. public reason is right because public reason says so. A theory of knowledge 
can resolve these difficulties by showing how moral and empirical claims can be justified, which in turn creates the possibility that rules of political argument can be evaluated by examining the moral principles they invoke and the discourse they produce.

The stronger Habermasian argument for public reason derives the need for rational communication from the "intersubjective" origins of knowledge, especially moral knowledge. Intersubjective, in this account, means that moral claims are a kind of knowledge: they can be true or false, there can be reasons for believing them true or false, and these reasons can be judged as sufficient or insufficient for moral beliefs, but these reasons cannot be deduced from unchallengeable axioms and must therefore be developed and verified through dialogue (Fullner (ed.) 2011). This partially stems from the question of informed disagreement: how does one evaluate competing claims from people with the same reasoning ability and relevant knowledge? The most tempting approach is to look for a higher-order principle or new piece of evidence to resolve the dispute, but this requires something beyond the existing stock of knowledge and methods of thinking (Feldman and Warfield (eds.) 2010). First principles, by definition, cannot appeal to subsequent specific knowledge claims to justify themselves and must therefore be immediately apparent to the reasonable mind, a problem parallel to the impossibility of justifying public reason via public reason. Principles for resolving this sort of "peer disagreement" come into play because common reasoning methods and available facts give each reasoner grounds for accepting their opponent's argument and mean that they cannot automatically trust their own in the absence of a clear advantage; the disagreement may reflect an error in each reasoner's thinking of which they cannot be aware (Feldman and Warfield (eds.) 2010). The problem of peer disagreement therefore leads to an intersubjective 
origin for moral and to a lesser extent empirical knowledge, provided that the people reasoning/arguing together have a minimum level of thinking ability and access to the same sources of knowledge; justifying a moral principle requires making it intelligible to other minds which may hold conflicting ideas, which in turn requires that the principle can be communicated in full to anyone capable of understanding it (it cannot be by nature based on unshareable knowledge or logic), and its plausibility must be perceptible to such minds (Fullner (ed.) 2011). This partially holds for empirical knowledge as well; reasoning about the properties of the physical and social worlds, can still run into the disagreement problem if a limited available stock of information lends itself to multiple equally defensible interpretations. Political justifications necessarily include both moral claims (what the government ought to do) combined with empirical ones (the predictable consequences of a given political action, which will determine its moral worth); any argument for political action can therefore run into the peer disagreement problem without any potential appeal to first principles, which in turn requires that such a political argument be judged according to its comprehensibility to other potential reasoners. Rules for public reason can then be justified as the most effective way to protect and encourage the pursuit of truth, using evidence defensible without tautologically referring back to the rules of public reason themselves.

\section{3: The Anti-Realist Challenge, and its Answer.}

The intersubjective account of knowledge presumes a world common to and directly or indirectly perceptible by all participants in a discourse, because reasoners cannot evaluate each others' ideas or evidence if they only have access to private worlds and private knowledge. This makes any challenge of the concept of shared reality, a challenge to any proposed rules of 
public reason. The most direct of these challenges to the possibility of public reason are a set of arguments that come together under the broad heading of epistemic relativism, stating that knowledge claims are variously the product of cultural contexts, specific interests and/or enforced epistemic regimes and cannot be separated from these contexts to grasp universal truths. These arguments against shared access to a mind-independent world, prove incoherent; their failure illustrates the need for philosophical realism in political argument.

Public reason cannot function without the concept of truth: intelligible statements that capture aspect of the things they address regardless of the perspective of the speaker or the listener. The constrained version of public reason attempted to avoid the question of truth in favour of evaluating political claims on reasonableness in order to prevent conflicts associated with mutually exclusive truth claims, but this failed even as an argument from expediency since doctrines with competing claims will still deny each other's reasonableness (Cohen 2009). The constrained version of public reason also had to address the question of truth due to its derivation from the notion of justice as fairness (this notion of justice had to be true); the concept of truth must therefore be agreed by public reasoners to be admissible in public reason as a way to judge political statements, though this does not require a particular definition of truth (Cohen 2009). The need for the broader version of public reason, as opposed to private reflection or expert diktat, comes from the communicative process needed to discern moral and empirical truths as mentioned above. These truths must therefore, in principle, be universally understandable and supported by evidence that a rational thinker of any origin can evaluate. Understanding need not be based solely on evidence readily available to a layperson, but expert knowledge alone is not sufficient or necessary for arguments grounded in public 
reason and any argument from expert knowledge must still in principle be open to comprehension and evaluation by an ordinary citizen. Any limits on the scope of truth therefore weaken the case for public reason and restrict its scope. Public reason cannot survive epistemic relativism.

Public reason's need for justification by appeal to truth, makes it vulnerable to attacks targeting the universality of some or all kinds of truths. Specific critiques of the exclusion of pure emotional experience from public reason, derive their force from the denial of universally accessible truths. The case of the debate within American black churches over gay marriage will illustrate. A number of black preachers who supported gay marriage, deliberately avoided arguing from scripture or felt revelation in favour of arguments from natural and constitutional rights (Johnson 2015). Such arguments fit into both the narrow and broad criteria for public reason; they could plausibly be said to fit into some kind of overlapping consensus, as they appealed to a founding document and underlying assumptions about rights that are recognized by the government and by an observably large number of its citizens. It also appeals to the notion of a possible shared understanding of moral truths, in this case the existence of specific rights. This approach is nonetheless criticized as an example of public reason's failure to accommodate "epistemic diversity" on the grounds that it ignores felt experience. The experience of "double consciousness" (i.e. having to deal with one set of rules and assumptions when interacting with non-black society, before switching back to an authentic black identity) carries moral weight in politics and public reason is therefore flawed if it fails to integrate this experience into political discourse (Johnson 2015). This critique does not pose a threat to the concept of public reason if public reason can appeal to at least a common understanding of 
truth, let alone a common precise definition. The reasonableness of arguments from double consciousness could be evaluated based on accessibility of the evidence presented for it to a person without direct experience, and then the relevance of such verified facts to the moral and legal status of gay marriage. Public reason would fail to admit such an argument because the evidence for double consciousness claims comes from feeling and therefore cannot be accessed by public reasoners other than the people making the claim; the same limits on emotion as evidence prevent arguments from religious revelation from gaining legitimacy under public reason (Rosenbaum 2009). The call for "epistemic diversity" is therefore irrelevant as such diversity includes evidence that by nature cannot be accessed by other public reasoners. This exclusion depends on the shared concept of truth and agreement that such truth can be commonly understood. That is, without a common standard of judgments, claims about the existence of double consciousness and their relevance to a political issue, would either have to be taken on faith in the claimant's direct experience, or dismissed without the possibility of justification. There would be no argument to submit to the public reason of the citizenry. The argument in favour of such evidence therefore has to come from limits on the comprehensibility of truth, which creates in principle the possibility that citizens responding to unavailable sensory or emotional evidence from other citizens have to take such evidence and its relevance on faith. This case offers only a local challenge to the legitimacy of public reason in that only a certain kind of knowledge- felt experience- is in this case too innately subjective to meet public reason's evaluative criteria; a broader example could invalidate public reason as a whole. 
Brexit and Trump's election as President, offered opponents of public reason a chance to attack it by attacking the notion of communicable and universal truth that underlies it. This attack begins by attributing a surprising failure of democratic norms and of reliance on facts, to “knowledge"-producing experts' unwillingness and/or inability to engage with competing narratives. This problem supposedly emerged due to the "arrogant" insistence of science (at the level of method and premises as well as of individual scientists) in drawing a hard distinction between true and false and thereby failing to notice competing "truths" that rose up in opposition to their claims. It also abandoned subtle shades of differing opinion in favour of drawing a hard line between true and false claims, potentially exacerbating existing tendencies towards polarized and mutually exclusive beliefs. Scientific claims that global warming was a real phenomenon, for instance, did not incorporate the truths of "hardscrabble blue-collar workers", so that a truly democratic integration of competing narratives never occurred and those who opposed environmental policies for emotional and economic reasons instead expressed their truth by voting against said policies (Jasanoff and Simmet 2017). This resulted in a standoff between Trump's supporters and the scientific community, with proponents of science attempting to "beat Trump over the head" with purportedly universal truths that were in fact the product of specific circumstances and interests (Jasanoff and Simmet 2017). This alleged problem could be addressed within the broad rules of public reason given a shared understanding of the existence of truth and basic criteria for considering something to be "public knowledge": claims of rising global temperatures and disappearing blue-collar jobs could be evaluated for evidence communicable to the whole of the citizenry, and the moral and material implications of possible policy responses compared using the same criteria. Climate 
change and unemployment are both phenomena comprehensible to reasoners who do not experience them directly, albeit through the medium of statistics, and claims about one do not necessarily invalidate claims about the other, so differing truths do not compete in this case unless their evidence and moral weight is, by nature, impossible to judge, for people who do not hold these localized truths to begin with. This would also reduce the danger of motivated reasoning by making arguments less dependent on the motivations of their proponents. A common standard of evidence and reasoning method allow citizens to judge both rationalizations and sincerely held beliefs on their own merits. A politician may claim scientific justification for a purely political move and find their claims confirmed, while their sincere opponent may make a good-faith argument that is later falsified. This in turn is only possible in the complete absence of a common epistemology.

Standpoint epistemology, a restatement of epistemic relativism, provides the philosophical backing for the kinds of specific complaints mentioned above. Its assumption of the incommensurability of perspectives, and the consequent challenge it presents to any account of public reason, can be seen in response to a critique of intersectionality. The criticism, applicable to epistemic relativism as a whole, is that using identities-gender, race, sexuality etc.- as units of analysis and then combining them in a single person, logically leaves any given person unable to speak for or analyze the claims of any other due to their incomparable experiences, making political claims impossible to justify (Harding 1997). An empiricist could try to solve this problem by arguing that feminist knowledge claims can be evaluated and confirmed like other knowledge claims (Goldenberg 2017), but the standpoint epistemologist's response is to deny the critique's universality by pointing to the critic's 
“managerial" perspective (Harding 1997). Reducing a person's argument to their position, allows the standpoint epistemologist to ignore any universal claim that might offer a basis for political action or a criticism of same, provided that standpoint epistemology can itself be justified. Privilege-checking dies without epistemic relativism.

These specific and general criticisms have to draw on a localised form of epistemic relativism: the belief that knowledge claims are limited by human subjectivity to claims valid for a local situation, and cannot be considered knowledge when taken out of this context. The absolute version of epistemic relativism states that all knowledge claims are necessarily restricted to the social/cultural context that created them, meaning no universal knowledge of the kind required by public reason can possibly exist. This absolute form is easily dismissed by pointing to its internal incoherence; epistemic relativism is either universally true, in which case it refutes itself by producing a piece of universal knowledge, or relatively true, in which case it only applies to the context which created it (Boghossian 2006). The more limited and plausible version of epistemic relativism avoids this problem with a more limited claim about "epistemic regimes": the notion that different methods of producing and evaluating knowledge evolve in different social and cultural contexts. These epistemic regimes can only be evaluated on their own terms, as the specific origins of all such regimes do not create the opportunity to develop a universal method transcending them, and therefore no claim made from a given regime can be judged true or false by someone outside it (Boghossian 2006). This claim avoids immediately falling to internal incoherence by restricting its claims to competing epistemic regimes and allowing for the evaluation of statements on a regime's own terms, rather than declaring knowledge completely relative down to the level of individual claims (Boghossian 2006). A given 
regime, such as the scientific method, the study of history or examination of sacred texts through the lens of theology can still make judgments about statements within its domain. This level of relativism, if true, still renders public reason impossible to conduct or justify. Different epistemic regimes cannot evaluate others' claims or make arguments that can be evaluated by others, so the common standard of knowledge necessary for public reason cannot exist in any society where more than one regime has any adherents. The scientific method, for instance, makes and evaluates knowledge claims based on a more rigorous form of the empirical reasoning humans use in day-to-day life to understand and navigate the material world (Badiola 2018), and therefore could not make sense of religious knowledge claims grounded in the felt experience of religious revelation (Rosenbaum 2009). Any political debate that brought such different epistemologies into direct conflict, such as an argument for the physical evidence of global warming versus religious claims that the world will not be destroyed until the supreme being does it himself, would be in principle impossible to resolve. Any defense of public reason has to address the threat posed by this specific form of relativism.

The theory of competing epistemic regimes still creates incoherent claims, and in the process reduces the possibility that basic differences between systems of discovering and evaluating knowledge exist or are even possible. The epistemic regime theory's incoherence emerges when different systems produce mutually exclusive claims, which the opposing claim's system is incapable of evaluating. Different epistemic regimes produce knowledge claims which are true on the regime's own terms, so if different regimes produce mutually exclusive knowledge claims they both must be true. The theory of incomparable epistemic regimes therefore invalidates itself by creating incoherent knowledge claims even when the theory itself 
is not self-contradictory (Boghossian 2006). In addition to this conceptual problem, it is in practice difficult to show that apparently different epistemic regimes actually have different basic rules for making and evaluating claims about the observable world, as opposed to different specific claims or special pleading for the existence of things not seen. A Papuan tribe's belief that witches are responsible for spoiling food or knocking over food stores, for instance, may not come from the tribe's having a different understanding of knowledge but because food spoilage and property damage generally occur shortly before or after natural events traditionally attributed to witches, and the tribespeople have mistaken correlation for causality (Boghossian 2006). The limited form of epistemic relativism therefore suffers the same fundamental problems as the general form, and is no more effective an argument against public reason.

The problems of epistemic relativism reveal that perspectives are no substitute for shared mind-independent objects. Epistemic relativism and its derivatives collapse into selfcontradiction precisely because they cannot provide any grounds for assuming a shared reality accessible to all citizens. The limited reach of any knowledge claim, carries the inherent possibility that a mutually exclusive but similarly relative claim must also be considered true, which mandates either a complete lack of shared context (impossible in any polity where citizens of different opinions have to decide matters of common concern) or the logically impossible belief that contradictory claims are simultaneously true. Realist epistemology avoids this problem by pointing to the existence of a world independent of any particular mind and grounds for considering it knowable. The epistemic relativist critique of realism, ultimately reinforces the case for realism in public reason. 


\section{4: Can Mere Humans be Public Reasoners?}

Habermas' intersubjective account of knowledge comes into play when considering both the existence of objective truths and the limits of individuals' reason in comprehending them. Humans' cognitive limits pose a second challenge to public reason, in that they cast doubt on whether debate and decision based on a shared commitment to rational fact-finding are possible, but this problem can be solved by pointing to the role of argument between people and groups in developing knowledge claims; no one person needs to be perfectly rational, because the partially-rational arguments of multiple people can provide a complete picture when combined and evaluated in light of one another.

A shared epistemology in politics is, in principle, possible, but this is meaningless if it demands too much of politically active citizens' knowledge base, thinking abilities and/or dedication. A moral rule therefore has to meet at least a minimum standard of possibility: a rational actor, acting in good faith, must in principle be able to act in accordance with the rule (Newman 2015). The rules of public reason have to go beyond this minimum standard since they apply to any citizen who publically makes claims about political decisions. While Rawls' initial conception of public reason appears to be modeled on graduate seminar discussions (Hedrick 2010), it will in principle be used by citizens without extensive background knowledge of every or even some major policy problems or expert knowledge of a specialized field immediately relevant to government policy, such as medicine or law. Public reasoners, whatever their expertise, will also have a limited amount of time to evaluating political arguments and options (only so many hours in the day, and humans also need to sleep, eat, earn legal tender and handle the concerns of friends and family) and will have varying access to 
relevant information. These limits exist before public reason takes into account the difficulties that human brains have thinking reasonably. The rules of public reason must therefore accommodate the limits imposed by human reasoning capabilities, the sources of information available to most citizens and the level of expertise a citizen can reasonably be expected to possess in political matters not related to their profession.

Readily available, accurate information and reliable expert advice, do not matter if citizens are not psychologically capable of forming it into arguments that meet the criteria of public reason. The first problem is that humans make predictable errors in reasoning regardless of educational level, intelligence or emotional state. This allows an attack against the possibility of communicative rationality as a whole and rationality in political argument in particular. The ideal of communicative rationality (in which reasonable people arrive at defensible conclusions about the state of the world and the nature of morality by trying to make their beliefs comprehensible and acceptable to other reasonable people, as described above) requires that rational communicators evaluate evidence with an open mind, do not misinterpret what others say and draw conclusions that flow logically from the evidence and arguments presented. These expectations do not match observed flaws in human reasoning. The pros and cons of a given political decision, for instance, are inherently difficult to weigh when the people weighing them are biased towards certain outcomes over uncertain ones even when the probability of an uncertain outcome can be calculated and shown to produce equal or better consequences on average than the certain one (Hook and Rienstra 2006). Evaluating evidence is similarly difficult when different ways of presenting the same evidence can cause people to focus on different parts of a claim and change the amount of significance they attach to it when making decisions 
(Hook and Rienstra 2006). These predictable errors create problems for public reason whether people makes arguments in good or bad faith. Good faith arguments can still be undermined by errors in reasoning, if the person making the argument inadvertently over-emphasizes pieces of evidence based on the way they are framed or the listener makes similar mistakes. A bad faith argument can be made more persuasive if speakers deliberately make their proposals seem more urgent or attractive than they really are, for instance by using a certain but very rare bad event to justify policies that have a high (but not certain) likelihood of causing greater harm to a larger number of people. Justifiable rules of public reason, have to include plausible rules for either stopping errors in reasoning from slipping into public political statements or, more intuitively likely, minimizing the effect of such errors once they get into public discourse. Solving the problem of predictable reasoning errors, would still leave the danger that citizens will be too emotionally invested in non-rational doctrines to use public reason, even if they are aware of its demands and capable of compensating for reasoning errors. Religion, based in revelation, is the most obvious form of non-rational attachment, but secular beliefs can similarly form into emotionally powerful non-rational doctrines in the form of a "deep story". First defined when observed in Tea Party supporters in the United States, a deep story is "a story that feels true" (Hochsild 2010). Such a story may or may not be supported by verifiable evidence, but evidence is irrelevant to its adherents because it satisfies emotional needs and reassures them of their moral worth and social status. Louisiana Tea Partiers' common deep story told them their perseverance, work ethic and piety were not fairly rewarded by America's leaders, who instead spent their reserves of pity and compassion on immigrants, poor non-whites and other outsiders (Hochsild 2010). Specific statements within 
this deep story could be shown to be factually wrong- rates of welfare fraud were much lower than Tea Party supporters believed, for instance- but such facts did not change adherents' belief in the deep story (Hochsild 2010). Public reason cannot accommodate the use of deep stories as arguments for political decisions. The lack of any necessary connection with verifiable evidence and a deep story's necessary reliance on the felt experience of its adherents, means that a deep story does not constitute a valid argument, just as the felt experience of dual consciousness mentioned above had no bearing on the moral status of gay marriage. Rules of public reason can exclude the overt introduction of deep stories into political debate, but this does not guarantee that deep stories will not covertly determine the fate of political arguments. Public reason arguments that conceal arguments from deep stories, can create flaws in the arguments and deprive other listeners of information needed to evaluate them. Insincere public reasoners may fail to convey their views correctly if they translate them from the terms of their deep story to arguments comprehensible to others. The overall level of support for a particular deep story may not be visible to citizens who have to factor that deep story's supporters into their calculations, and deep story supporters will not necessarily see flaws in their arguments stemming from their beliefs (Schwartzman 2011). A liberal society gives citizens the option of exit: a citizen whose beliefs do not meet the requirements of public reason, can remove themselves from public deliberation rather than continue to expose themselves to a process that excludes their beliefs (Vallier 2018). This leaves the rules of public reason undamaged but may partially defeat their purpose; overlapping consensus, in Rawls' narrow definition of public reason at least, can be interpreted as a social stabilizer as well as an end in itself, since it allows holders of opposing comprehensive doctrines to co-exist in a 
democratic state (Zoffini 2012). Rules for public reasoning would therefore have to handle nonrational belief systems like deep stories in the same way it handles persistent reasoning errors: either restrict their influence on citizens' thoughts to non-political situations, or minimize their effect after they have entered public political argument. Public reasoning rules must also allow deep story adherents some reason to believe their beliefs will be heard, even if only indirectly through public reason arguments.

Removing the cognitive and emotional obstacles to public reason still leaves the problem of information: perfectly rational citizens will still have different levels of common knowledge and relevant expertise, which has to be made as widely accessible and comprehensible as possible. Differences in expertise are powerful enough to undermine the principle of overlapping consensus. Scientific knowledge claims might be repeatedly verified within the scientific community until they lose any hint of controversy (Badiola 2018), but they still come from a professional community with no connection to the overlapping consensus that guides lay citizens. Public reason deals with moral rather than empirical questions in any case (Kappel and Jonch-Clausen 2016). This strengthens the case for shared epistemology over a direct overlap between competing doctrines. Shared epistemology also helps connect the lay citizen to expert knowledge, since specialized forms of knowledge production like the scientific method expand on normal day-to-day approaches to knowledge rather than replacing them (Badiola 2018). Expert knowledge also points to the difficulty in getting people to abide by a shared epistemology when much of the information it accepts and relies on, comes from a small fraction of the population whose expertise cannot be easily transferred to the majority of citizens. An obscure branch of physics, for instance, may produce knowledge claims that are 
true and can in principle be understood in all cultural contexts and regions, but very few people will have the training to grasp the fine details of these claims or the process and evidence that validates them. The broad points of a knowledge claim from an esoteric field may be comprehensible to a rational layperson, but the details and justifications may also have to be taken on faith that the evidence was collected and assessed properly.

Each of these cognitive limits can be mitigated by mutual evaluation. Emotional attachment to a particular position, for instance, will vary from person to person; several committed partisans with opposing beliefs will offer strongly-felt argument for opposing positions, following which those citizens without emotional attachment to a specific position, can evaluate the strength of these arguments. Different areas of expertise possessed by different citizens, can similarly be introduced into a common dialog provided that the expert's conclusions can reach interested citizens in a comprehensible form and reasoning, and if the evidence behind them can be understood in general terms. Communicative rationality allows realism to function in public discourse, because it does not rely on each citizen being perfect rational but instead looks to each citizen's partial capacity for reason to spot and correct the mistakes of their peers.

\section{5: Necessary and Sufficient Conditions for Public Reason.}

Public reason requires only that politically-engaged citizens accept the existence of a world that exists outside of their minds and that consists of objects the properties of which can be known directly through verifiable methods. The most basic components of functioning public reason are therefore the intellect and mores of the individual citizen; the problems raised for public reason by larger structures and social forces, such as the reliability of the mass media or the 
balance of power between various social classes and interest groups, cannot be addressed unless and until a critical mass of the citizenry accepts realism as the basis of political argument and has the basic mental skills to apply it. Nor can the public spot and try to change the behaviour of governments that try to avoid or destroy public reason, unless they have the intellectual skills to spot violations of the rules of public reason. The necessary and sufficient conditions for public reason are therefore the presence of specific mental capacities and habits, and the will to use them, in a critical mass of the citizenry.

The first and most obvious necessary condition is that citizens refrain from importing anti-realist arguments or forms of reasoning into political argument. Citizens can hold spiritual or subjectivist beliefs in private without threatening public reason, since individuals' behaviour varies widely depending on context, to the point where people apply their comprehensive doctrines differently or not at all in the public sphere (Newman 2015). A religious devotee who beliefs in imperceptible spirits or deities, can set these beliefs aside when arguing over politics or policy and refer solely to phenomena that non-believers can verify, without necessarily compromising their private religious convictions. Nor is spiritual rhetoric automatically excluded; religious language may be necessary to communicate reasonable arguments to a religious audience, and religious style does not exclude realist substance (March 2013). This is possible, not guaranteed. Citizens can and have politicised their beliefs in things beyond the reach of human reason, and public reason weakens in proportion to the number of citizens who do.

The logical follow-up to this is that citizens who accept realism, also have to be able to evaluate claims in light of realism. This requires basic thinking skills such as the ability to tell 
when a given argument is actually relevant to the topic under discussion and supports the speaker's position (Astourian 2018), and depending on the policy area may also require a minimum level of general knowledge, such as basic numeracy when evaluating statistics provided by governments, political parties and interest groups. Critical thinking skills are used to evaluate new information, making them a precondition for acquiring knowledge, so the ability to think provides a better measure of the state of public reason than rote learning.

The first two conditions do not mean anything unless citizens learn and debate political topics; active interest is therefore the third necessary condition of public reason. The sheer weight of available information and number of political topics means that no citizen can reasonably be expected to have knowledge of and interest in every question that might require the use of public reason. Citizens can, however, reasonably monitor public sources of political information for topics of unusual importance and then focus their attention on the most important matters, barring a complete break between importance and newsworthiness (Moe and Ytre-Arne 2018).

An examination of public reason in Canada, entails measuring the average epistemic beliefs, critical thinking skills and political interest of the Canadian citizenry. It is to the state of Canadians' minds that we must now turn attention. 


\section{Part 2: The State of Public Reason in Canada}

\section{1: Absence of Subjectivism.}

Public reason will not work unless citizens accept the existence of a shared world that they can all comprehend; this means that majority belief in the superiority of subjective and revealed truths will make public reason impossible. Widespread exceptions to the limits public reason imposes on acceptable forms of argument, for instance the introduction of certain types of religious content (as opposed to rhetorical style) as specific accommodations, prevents meaningful action coming out of public debates by letting holders of comprehensive doctrines obstruct discussion by appealing to doctrines not rooted in commonly acceptable facts (Astourian 2018). The two most noticeable of these threats, are . First, dogmatic politicized religion can inspire its followers to introduce arguments based on the revelations their religion takes for granted, rather than perceptible things which nonbelievers can access. Second, and more insidiously, self-made belief systems can equate personal feelings with facts and privilege intuition and personal experience over shareable evidence. The first type of subjectivismdogma and revelation substituting for realist argument- has a limited but noticeable place in Canadian politics, influencing government regulation of sexual behaviour and private medical decisions. The second type has a large indirect effect on Canadian political discourse: do-ityourself epistemology, privileging personal experience over objective fact, manifests in a distrust of traditional knowledge-producing institutions beyond what can be justified, and a parallel increase in self-chosen anti-realist beliefs till they threaten to dominate citizens' thinking. 
The Canadian public's religiosity has declined in recent years, but religion has directed and continues to direct government policy regarding private sexual behaviour and education. The highly religious portion of Canada's population has dropped from its post-war peak of $60 \%$, but Alberta and New Brunswick retained slightly higher levels of devotion than the rest of Canada (Rayside, Sabin and Thomas 2017). This might have made religion politically irrelevant, if a fixation on private sexual and medical behaviour had not created new alliances of convenience between religious groups. All the religious texts of the major monotheisms include long and detailed prescriptions on sexual behaviour and gender roles (Napier 2015), and different denominations and religions increasingly joined forces to prevent governments from enabling or protecting actions that contradicted these rules. Abortion was the first issue to create a cross-denominational movement opposed to the attempted expansion of sexual freedom. New Brunswick's restrictions on effective access to abortion provided an early example of cooperation between adherents of competing comprehensive religious doctrines on a narrow social issue. Neither Conservative nor Liberal governments willingly expanded the ability of free clinics to provide abortions, and Frank McKenna's Liberal government responded to pressure from backbenchers with active support for restrictions (Rayside, Sabin and Thomas 2017). New Brunswick's political parties used to divide along denominational lines, but starting with this case unity between previously opposed denominations allowed a shrinking religious population to determine government policy (Rayside, Sabin and Thomas 2017). Similar rossdenominational efforts then emerged in Ontario and Alberta. The first such efforts appeared with resistance to gay marriage and then continued with opposition to proposed sexual education curricula in Ontario and Alberta. The Alberta government passed the Human Rights, 
Citizenship and Multiculturalism Act in 2009, which required that parents be immediately notified of their children's involvement in gay-straight alliances. In Ontario, Conservative Catholics and evangelical Protestants congregated around the Conservative Party under Tim Hudak in the 2011 and 2014 provincial elections (Rayside, Sabin and Thomas 2017). Crossdenominational alliances give religion a greater role in politics than the citizenry's declining piety would suggest. In these cases, scriptural authority serves as a substitute for the realism that public reason depends on, since the authority of these religious texts ultimately derives from the assumption that they were divinely dictated or inspired, and such a revelation is beyond the direct experience of the faithful let alone those who are not conditioned to accept scriptural authority without concrete evidence. Direct revelation is not accessible to somebody who does not experience it, and the feeling of contact with a deity is not by itself proof of that deity's existence and interest even if the experience is shared, which allows multiple conflicting claims of revelation to compete with each other and with secular belief without any commonly accessible evidence to conclusively resolve their competing claims.

The direct influence of religious doctrine can be partially contained by party discipline, provided that party leaders can effectively control both caucus, and provided that membership and adherents of politicized religion do not hold the balance of power within a major political party. Stephen Harper was mostly able to suppress and ignore the demands of the Conservative Party's religious social conservative wing during his time as Prime Minister (2006-2015), most notably by refusing to re-open debates on abortion and same-sex marriage (Rayside, Sabin and Thomas 2017). Canada's unusually strong party discipline allowed its political parties to steadily retreat from religious rhetoric even as the United States and Australia, sharing a language and 
(broadly) a system of representative government, incorporated steadily more religious content into their political rhetoric (Gin 2012). Canada's relatively secular political rhetoric came from the concentration of power in Prime Ministers' and party leaders' hands rather than from an absence of politicized religious dogma; Stephen Harper still had to contend with a social conservative wing within his party (Rayside, Sabin and Thomas 2017), while adherents of politicized religious dogma were also a minority in Australia, but due to the distribution of support between parties held the balance of power in several governments (Gin 2012). The centralised structures of Canadian political parties and governments do not by themselves guarantee that religious activists will not import their dogma into political argument. A centralizing leader sympathetic or beholden to the politically religious, or a weakening of party or government structures that allow a focused religious coalition to hold the balance of power and dictate policy on private behaviour, could introduce religious dogma into party platforms and government legislation.

Politicised religion has two indirect forms of influence over public discourse in addition to the direct effects of religiously motivated political partisans: "disruptive" interventions by religious groups that make strong emotional attachment to dogma grounds for legal accommodation, and the introduction of notions of the sacred into secular language through the "translation" of religious into secular arguments and vice versa. "Disruptive" interventions in public life by people seeking religious accommodation, do not necessarily pose a threat to public reason. Such interventions can be framed as appeals for established rights, such as the positive right to practice religion, which could be unfairly restricted for a particular group if it is disproportionately affected by a law meant to regulate religious practice in general (Napier 
2015). The potential threat to public reason comes when debating the rationale and scope of accommodations. Providing an exemption to a law or institution's private rule on religious grounds, may allow citizens unhappy with a rule to claim freedom from it based on the emotional power of their beliefs and personal experience of faith, rather than arguing against it based on facts that the rest of the citizenry can access. A case in which the court allowed a Sikh to carry a kirpan (ceremonial dagger) to school will illustrate. Public reason offers considerable room to argue for allowing a student to carry a knife to school, for religious or utilitarian purposes. A public reasoner could point out that the person carrying the knife has no history of violent or aggressive behaviour (appealing to verifiable facts about the knife-carrier's personal history), that a knife may have practical non-violent uses in addition to its ceremonial importance, and/or that the hilt could be bound to the sheath, preventing it from being drawn on school grounds. None of these arguments privilege the subjective experience of faith or revelation, and they can all be used to argue against an overly restrictive general rule without requiring a special exemption from it. An argument from subjectivity, such as a redefinition of a kirpan as a religious symbol rather than a sharp object even though it is both or that the psychological power and social constraints of religious belief limit the degree of to which religion is a choice (Napier 2015), privileges personal feeling over appeal to or criticism of common rules. The objection to such exemptions comes from the principle of fairness, in turn derived from the basic legal ideal of equality of persons: a universal rule may burden adherents of some beliefs more than adherents of others, but as people have the power to change their beliefs and expressions of their beliefs a law can be considered fair as long as it does not directly target a specific group (Napier 2015); to do otherwise risks introducing arguments from 
power of religious feeling into legal and public discourse, leading to the weakening of public reason that naturally follows from successful special pleading (Astourian 2018). In this case the courts decide whether particular accommodations can be reconciled with 'a free and democratic society' (Government of Canada 1982), which means that the extent to which subjectivist special pleading can become legally binding, depends upon the uncertainties of the courts' interpretation of law.

The response to such an argument demonstrates the potential threat that "disruptive" interventions pose to public reason. First, appeals for special dispensation can be justified by denying the possibility of government and public discourse remaining religiously neutral. In other words, claiming that it always implicitly endorses a doctrine under the guise of neutrality and therefore that "dissensus" (constant argument over basic principles as well as specific issues) is both inevitable and preferable to acceptance of apparent neutrality. The Canadian government's apparent religious neutrality, for instance, is presumed to conceal an implicit and unacknowledged bias towards Christian assumptions and ways of acting (Dick 2016).

Outwardly-universal rules that disproportionately affect religious minorities, such as Quebec's recent attempt to prevent public servants from wearing conspicuous religious accessories, are therefore a normal feature of "Christian liberalism" rather than an aberration (Dick 2016). Muslims' legal challenges to this law, citing the Charter of Rights and Freedoms, are worthwhile because they are "strategic disruptions" of a disguised hegemony of Christian mores (Dick 2016), not because they appeal to a common set of legal facts (the relevant prior case law and the Constitution's explicit statements on religious freedom). If coercive bodies such as governments are unable to act as neutral arbiters and instead represent disguised hegemonic 
ideas, and if challenges to partial laws are desirable because they overtly press a competing religious idea rather than by appealing to shared ideals and facts, this implicitly raises the incoherence problem created by epistemic relativism. This logic would make public reason impossible if it was universally adopted; if coercive institutions cannot be trusted to act impartially and commonly acceptable arguments cannot exist or cannot provide the basis for creating and interpreting law, then "strategic disruptions" to make space for an unverifiable but powerfully felt comprehensive doctrine, make far more epistemic and political sense than appeals to a non-existent set of common principles. This would logically lead to every group with a distinct comprehensive doctrine that resists outside evaluation to press a claim on the same grounds when confronted with a general law that restricts its activities. This threatens public reason insofar as such groups successfully argue that their religious doctrine and experience by themselves override secular concerns such as public safety or protection of the rights of the irreligious; arguments that appeal for a general change to a law based on these shared standards do not pose a threat. "Disruptive" interventions that are consciously designed to challenge the notion of a religiously neutral order, would therefore undermine the official religious indifference that protects religious minorities and weaken public reason in the process. This makes public reason in Canada, partially dependant on the self-restraint of those who seek official recognition and accommodation for their subjectivities, or failing that on the resistance of courts and governments.

Politicised religion rooted in revelation can subtly drive political discourse away from the realism public reason requires, through the process of "translation". This process entails converting secular statements into religious ones and vice versa; the concept of translation 
enters the process because the meanings of statements cannot be readily detached from the background knowledge, assumptions and connotations these statements acquire in the religious and cultural communities that produce them (Napier 2015). Translation also allegedly allows sacred concepts to critique and offer alternatives to inadequate secular speech, with Martin Luther King and Gandhi providing examples of religious concepts deployed to critique secular oppression, segregation and disenfranchisement in the former case and British imperialism in the latter (Napier 2015). This leads into the concept of "prophetic witness", in which ethical claims appeal to religious claims and sacred precepts in order to reveal the flaws in dominant secular discourse. This offers an alternative to a rigid secularism which forces the religious to compromise their identities in order to participate in politics and which also excludes valuable contributions to public discourse (Napier 2015).

Translation and "prophetic witness" are both vulnerable to epistemic and practical objections. Epistemically, conflicts between different sacred texts or religious axioms can introduce mutually exclusive claims via the mechanism of "prophetic witness". Since this form of argument, by definition, relies on religious claims to critique secular ones, its claims cannot be judged by those who do not already accept witness as prophetic. The appeal to sacred axioms also creates problems when evaluating competing claims within a religious tradition. Conservative interpretations of Islam's pronouncements on sex and gender, for instance, were challenged by progressive Muslims offering a conflicting interpretation of the same texts during debates about same-sex marriage and sex education (Napier 2015). This necessarily requires deciding between mutually exclusive interpretations of the same authority, which in turn requires either relevant evidence from outside the sacred pronouncements (which have already 
been subject to competing interpretations), or choosing an interpretation when the choice is underdetermined by evidence. Religious witness in this case can offer a new form of rhetoric that can make public reason arguments palatable to a highly religious audience, as was the case in both the pre-Civil Rights American south and Apartheid South Africa (Astourian 2018), but this is not the same thing as a substantive appeal to religious authority since style is not substance. The epistemic problem leads to a practical one: any religious authority that lends itself to interpretation, can support divergent political programs and therefore cannot argue for a specific political program. Martin Luther King and Gandhi, cited above as examples of "prophetic witness", could appeal to generally comprehensible and defensible moral premises that did not depend on a sacred axiom: Martin Luther King appealed to principles of personal freedom and equality of persons and the democratic right to participate in public life, while Gandhi could cite the right of national self-determination that had been debated outside of any one religious tradition, as well as British suppression of Indians' political rights. Religious claims by themselves could not have given their political arguments a reach beyond those already committed to their interpretation of their religion. They had to reach beyond interpretation of sacred texts to find arguments compatible with public reason. The process of "translation" extends this problem, since it moves religious concepts into secular thinking. It involves translating concepts between otherwise incompatible contexts where the ambiguities of language are compounded by the connotations and idioms that each religious and cultural environment develops (Napier 2015), meaning the content of a concept as understood by a new listener, can change unpredictably when moved from context to context. This first creates an obstacle to public reason by diluting whatever common set of concepts and objects are 
agreed to exist and carry political weight. It then creates confusion which can allow the subjective experience of revelation and dogma to take on the appearance of claims about shared reality. A claim that a given racial or sexual group's experience is incommunicable to those more privileged, for instance, appeals to subjectivity over objectivity, but if translated from the language of personal experience into that of social science may take on the appearance of a verified scientific theory. Secular and sacred claims do not blend well in political argument; insofar as the sacred publically intrudes on the secular, public reason suffers. Translation and "prophetic witness" both pose this risk.

The problems mentioned above come from religions with some level of organization and common doctrine, but a distinct problem arises from individuals' decisions to form personal mystic beliefs out of their subjective experience, and privilege these beliefs over the shareable arguments that form public reason. This kind of do-it-yourself religion and epistemology, referred to as "I-pistemology", correlates with a measured decline in citizens' confidence in traditional knowledge-producing institutions such as newspapers and scientific institutions (Zoonen 2012). The rise of "I-pistemology" can be observed in a turn away from analysis of objects and phenomena in citizens' shared reality. Factual accounts in journalism and elsewhere have been partially supplanted by personal accounts privileging emotion and perception, following a trend towards subjectivity first observed in the feminist movements of the 1970's which later spread to other social movements (Zoonen 2012). This form of personalized epistemology does not allow for the possibility that the I-pistemologist may be misled by their experiences and emotions, or that certain things and phenomena may lie outside direct experience and therefore require specialized forms of knowledge production, 
such as scientific or historical methods. The practical consequence is a substitution of intuition and motivated reason for the investigation into shared reality that public reason requires.

"I-pistemology" commonly appears in political matters and serves to discredit outside sources of evidence for political arguments, in the eyes of the I-pistemologist. Believers in a link between vaccination and autism, a falsified hypothesis, buttress their beliefs with evidence selected to fit their preconceptions, but primarily by privileging maternal intuition. Surveyed American mothers who believed in the vaccination-autism link, when questioned about their beliefs, tended to fall back on the claim that they learned from the detailed experiences of other mothers rather than from a financially interested medical sector, and that they could feel that vaccines posed a threat (Carrion 2018). This response shows two key features of the epistemic relativist objection to realism. First, knowledge statements are assumed inseparable from their social context; in this case, anti-vaxxers assume that statements about vaccines' safety are purely attempts to protect drug companies' profits (this is not an automatically inaccurate assumption, but they would first have to show that the companies were wrong before citing bias). Second, individual intuition is considered superior to formal knowledgeproducing methods because the person intuiting things has a standpoint that an outside reasoner cannot access.

Similar assumptions appear in diverse settings in the form of "folk theories" and "deep stories" such as that absorbed by Tea Party members. Interview subjects in news stories, for instance, constructed their own accounts of the media's operations based on personal experience (reaching beyond what their experience could confirm) and taking their comments to be systematically distorted (Palmer 2019). These beliefs scale up from specific instances to 
general beliefs about politics. The "deep story" informing many of Trump's supporters, in which they were the targets of corrupt and contemptuous liberal elites, was formed from shared cultural myths and unverified claims transmitted via word of mouth rather than direct exposure to or confirmation of the claims, despite which the "deep story" seemed to be the product of personal intuition which its believers then privileged (Callahan and Polletta 2017). These personal intuitions show the key characteristics of "I-pistemology": blanket mistrust of knowledge-producing institutions and methods, combined with the privileging of personal intuition as a path to knowledge. This form of subjectivism allows its followers to assimilate new information to their personal deep stories when it suits them, and reject it when it does not. This has a direct effect on political argument.

Study of Canadian spirituality reveals the same turn toward "I-pistemology" observed in other developed western countries, posing a similar challenge to public reason. The idiosyncratic spiritual beliefs that appear to be partially replacing established religious dogma have alternatively been interpreted as individualist beliefs adopted in response to a capitalist culture that enforces competition and discourages collective effort, or as attempts to break away from and resist the "oppressive" existing spiritual authorities and political structures (Watts 2016). None of these structures- capitalism, the state or organized religion- appears to be on the verge of total collapse, so neither potential cause is likely to disappear soon enough to stop producing I-pistemologists. The individualist brand of spirituality has unavoidable political implications: it takes as given that a person's political energy should be spent privately developing their self, rather than trying to change political institutions or economic structures, and because this axiom supposedly comes from spiritual revelation it cannot be challenged by 
appeals to fact or common principle. The same problem would exist for personal spirituality devoted entirely to social justice: concrete political demands for representation by identity group (gender, race, sexual orientation etc.) would be grounded in mysticism incompatible with public reason. Investigation of personal spirituality, however, suggests that neither scenario completely applies. Private spirituality tends to originate in desires and experiences that lead people away from organized politics. Interviewees repeatedly expressed dissatisfaction with religious structures they deemed hypocritical or that they felt had dismissed their subjective religious experiences (Watts 2016). Personal spiritual beliefs therefore generally led to two general categories of social behaviour: attempts at self-improvement through introspection, and community engagement through non-governmental organizations (Watts 2016). In the former case, respondents repeatedly dismissed party- or government-level political participation as a way to change their environment for the better; their private faiths served as a form of private solace and motivation to find meaning in their lives without collective action (Watts 2016). The social justice aspect of private spirituality also seemed to stem from this private search for spiritual comfort; respondents frequently rejected organized religion because it did not feel correct in light of their perspective (Watts 2016), rather than from any explicit change in their ideas. Respondents similarly integrated their beliefs about the importance of representation and diversity into their spirituality because it gave them comfort and confidence and motivated them in their volunteering (Watts 2016). In these cases most respondents developed one or both of two beliefs highly relevant to political discussion- that attempts to change the behaviour of the state are irrelevant, and that social justice should be located primarily in culture- through emotion-driven introspection, without noticeable reference to 
study of the world outside themselves. This approach is the opposite of what public reason requires.

\section{2: Intellectual Interest and Competence.}

Even if most citizens are committed to realism, they still require basic skills and knowledge to learn and evaluate claims about their shared world. Said skills divide into three broad categories: general knowledge (necessary to understand in broad terms the arguments made by specialists in esoteric fields, relevant to complex issues such as environmental policy), critical thinking skills (needed to determine the relevance of evidence to argument, and evaluate the overall validity of an argument), and communication skills (needed to make an argument comprehensible to other citizens). Canadians, on average, demonstrate inconsistent abilities in these areas, which limits the citizenry's overall ability to apply realism to political argument.

Canadians' poor average scientific literacy can prevent the effective use of public reason regarding policy questions that depend on physical science. The Canadian population is bettereducated and appears more enthusiastic about the use of science to address political questions than most other developed countries, but despite a comparatively high level of enthusiasm and understanding only $42 \%$ of respondents to surveys about attitudes to science, demonstrated the minimum knowledge needed to understand science news stories written for a general readership (Council of Canadian Academies 2014). A majority of Canadians similarly lacked basic understanding of the scientific process: only $46 \%$ of Canadian adults interviewed could explain the basic steps of the scientific method (Council of Canadian Academies 2014). Knowledge of basic, established scientific pacts proved on average higher but still inconsistent. 
$87 \%$ of Canadian respondents correctly believed the Earth revolves around the Sun (compared to $73 \%$ of Americans), $58 \%$ recognized electrons as components of atoms, while only $53 \%$ understood that antibiotics do not target viruses and only $58 \%$ understood that non-GMO tomatoes contain genes (Council of Canadian Academies 2014). A large minority of Canadian citizens therefore lack basic understanding of scientific process and established knowledge, which limits their ability to participate in debates about public policy. An understanding of the capabilities and limits of antibiotics, for instance, has obvious relevance to government decisions about drug coverage and research funding, as well as design, implementation and basic citizen understanding of public health programs. A basic understanding of scientific methods is similarly associated with ability to tell valid from invalid research findings. Scientific education has at least a negative correlation with pseudoscientific beliefs such as ESP or young earth creationism, although this may be the result of self-selection rather than changes due to education (Dyer 2019). The lack of such capabilities correlates with the presence of comprehensive doctrines. A lack of these abilities, keeps a substantial minority of Canadian citizens from understanding scientific findings that are directly relevant to government policy, which in turn creates openings for arguments incompatible with public reason, from antivaccination claims to climate change denialism and more.

Canadians' civic knowledge is similarly spotty. Knowledge of various government programs and procedures is spread unevenly amongst the citizenry, which can potentially benefit public reason by allowing different citizens to contribute different knowledge and arguments about a given topic, but may also prevent mutual comprehension and evaluation. A noticeable split occurs between men and women in both the amount and kind of political 
knowledge possessed: men had a higher average level of "conventional" political knowledge (facts about the Prime Minister, Premier, Commissions of Inquiry etc.), while women on average knew more about how to access social services and seek redress for social wrongs such as child abuse or mistreatment by a landlord (Stolle and Gidengille 2010). Both groups showed large disparities between native-born Canadians and immigrants. In particular, immigrants were far less likely to know how to access necessary social services than native-born Canadians (Stole and Gidengille 2010). Differences in the types of knowledge members of different demographic groups are more likely to possess, do not, by themselves, threaten public reason, since people with different knowledge bases can make arguments based on that knowledge, and provided the information is accessible to other citizens and the arguments can therefore be evaluated. A lack of "conventional" knowledge can still limit citizens' ability to use public reason, since said knowledge includes basic information about political parties, government and the parliamentary system and is therefore necessary for handling larger systemic problems that determine the character of social service delivery (Stolle and Gidengille 2010). "Conventional" political knowledge also shows a divide between age groups, with average knowledge increasing with age and a persistent divide between men and women (Milner 2007). The divide in basic political knowledge cuts across regions as well as age groups. Young adults in Quebec were far more likely to follow political news, more likely to consider electoral politics a meaningful way to correct societal ills and more likely to intend to vote (Milner 2007). Political knowledge also correlates with the strength of views about specific issues: higher general knowledge went hand-in-hand with a hardening of citizens' attitudes about the proper balance of power between Canadian legislatures and the court system (Goodyear-Grant, Hiebert and 
Matthews 2013). The uneven distribution of political knowledge among citizens, is therefore sufficient to create different levels of public reasoning ability, since intersubjective justifications for knowledge claims require that citizens have a minimum level of shared knowledge allowing them to evaluate claims in light of their own experience and expertise, uneven basic political knowledge makes it harder for political dialogue to generate defensible knowledge claims.

Only part of the public has the base knowledge needed to engage in public reason; similarly, available data suggests that only a fraction of the public has the critical thinking skills needed to apply said knowledge. The case of new arrivals to university will illustrate. A 2017 survey of university-bound high school graduates in Ontario found that roughly half did not consider themselves competent to write a critical book review (in which the student would have to evaluate a long text for its arguments and evidence), nearly a quarter felt unable to assess a short article's merits, more than half had difficulty identifying the kinds of arguments made in an article and roughly a quarter felt unable to detect biases that may affect a piece of writing's argument (Cote, Grayson et al. 2019). The survey covered a large number of skills relevant to academia and the workplace but not to public political debate (thesis construction, for instance), but other items such as the ones mentioned above, also measure the capacity to evaluate truth claims in all contexts and to integrate them into an existing stock of knowledge, a basic requirement of public reason. The fact that only $44 \%$ of incoming students were deemed "functional", while 16\% were considered "dysfunctional"(Cote, Grayson et al. 2019), indicates that said students also frequently lack the thinking skills necessary to use public reason. The survey itself drew over a thousand respondents across five universities and showed little difference between pre-existing demographic groups, as first-generation university 
students, for instance, did not do better or worse on average than others (Cote, Grayson et al. 2019). This survey also sampled a growing proportion of the citizenry. The proportion of Canadians attending university has steadily grown during the post-war period, and a majority of Canadians graduating high school will move on to some form of post-secondary education. The critical thinking skills of students, therefore make an increasingly strong proxy for the critical thinking skills of the citizenry as a whole. The data on students, suggests many citizens are unprepared for public reasoning.

There is nothing inevitable or incurable about the intellectual and ideological obstacles to public reason. Differences in conventional political knowledge among citizens, stem from different experiences with governments and different needs for services, rather than from any innate fitness. University students' critical thinking deficiencies reflected a lack of existing learned skill, not necessarily an inability to learn these skills. Even i-pistemology developed due to the specific experiences and environment, as refracted through the distorting ideological prism of epistemic relativism. Beliefs and thinking habits can change. So, what is to be done? 


\section{Part 3: Policy Options}

\subsection{The Limited Role of the State.}

The federal and provincial governments are subject to common pressures which limit their ability to promote and maintain public reason. The most serious and persistent of these is the government's constant interest in protecting itself from criticism or embarrassment by limiting and controlling the release of information about government activities. This means it cannot be expected to encourage public reason by providing necessary information. It has a larger educational role, since public reason requires that citizens have sufficient basic knowledge and thinking skills to discover facts about their shared world, but such education can directly and indirectly challenge comprehensive doctrines with a large support base. A government concerned with perpetuating itself, may or may not be willing to pay the political cost of such a curriculum. The government has historically been most successful in promoting public reason, by preventing adherents of any particular comprehensive doctrine from gaining control of political discourse and policy-making, and this may be the most that can realistically be expected from it.

The government has little incentive to provide information on its inner workings or the private reasons for its decisions, which limits citizens' ability to reason about public issues. The Access to Information Act remains the primary means of securing information about government activity. Municipal and provincial as well as federal governments began to digitize and publicize information such as officials`expenses and components of municipalities budget (Davies and Lithwick 2010), but these are initiatives by individual governments rather than a coordinated attempt to publicize data in response to a country-wide rule. The Access to 
Information Act therefore represents the more consistent way of gaining information on at least the federal government's activities. The Act creates potential barriers to public reason by creating difficulties accessing knowledge of government: potential changes to civil servant behaviour, semi-arbitrary limits on requests and the large amounts of pre-existing knowledge, time and money that a citizen needs in order to pry information out of the government.

Analysis shows partial evidence that civil servant behaviour changes in response to increased transparency. The Access to Information Act came into force in 1983, and the following years saw cases of information being destroyed where the destruction was subsequently attributed to a fear of information requests. A particularly egregious example is the destruction of recordings of a key meeting between senior officials of Canadian Blood Services in 1989 during the Kreaver Inquiry (Badgley, Dixon and Dozois 2003). This specific example deprived the citizenry of information about the thoughts and actions of high-ranking decision-makers who had to respond to the AIDS crisis. Such knowledge could have helped the public understand the decisions that allowed a communicable disease into the blood supply, important information for a public reasoner examining potential changes to a major component of the public health care system. Government departments were subsequently repeatedly accused of using the letter of the Access Information Act to violate its spirit by interpreting its requirements as narrowly as possible (Nilsen 1999). Limited sampling of comparable government documents before and after the Act, did not show the consistent reduction in documentation that would be expected if the Act had made public servants wary of public exposure; this leaves the danger of government self-censorship unproven, but the small sample size is insufficient to confirm that such self-censorship is a myth (Badgley, Dixon and Dozois 
2003). There is still partial evidence that the government's professional bureaucracy will, in at least some cases, actively hinder scrutiny to protect itself and the elected government it serves, at the expense of citizens' ability to evaluate policy.

More clearly established and more worrisome, are the strenuous requirements placed on information requests before the government will respond; these requirements have the same effect as bureaucratic secrecy, protecting the government by limiting citizens' ability to evaluate its actions. Amendments introduced to the Act in 2019 are expected to make the problem worse by imposing more conditions, creating additional request requirements and allowing more grounds for refusal. Grounds for refusal are vague enough that different departments are able to interpret them differently and can therefore create their own pretexts for rejecting requests; the Act and amendments restrict requests for documents to "reasonable" lengths to prevent requests that in some cases such as tax records can run to 10,000 pages or more (Maynard 2019). The definition of a reasonable maximum number of pages per request, is defined by each department, with caps ranging from 500 to 1000 pages, while the larger amounts are required for information on large activities such as tax audits (Maynard 2019). The explicit criteria also create barriers to citizen learning by increasing the amount of time, money and background knowledge required to make an acceptable information request. The applicant must know the exact subject of the documents to be requested, the kind of documents (e-mail, powerpoint, memo, etc.) and the time period (Maynard 2019). Any applicant therefore needs detailed knowledge of a given department's intra and inter-departmental communication rules, the way it classifies information and its rules for storing it, specialized knowledge a regular citizen cannot reasonably be expected to 
know. A non-expert concerned about their disability tax credit, for instance, cannot reasonably be expected to know how a front-line worker would process an application, who would review it, whether this information would be stored in hard copy and/or electronically, whether any emails would be sent and when the application would be processed. Navigating this system requires time, resources and expertise that a regular citizen, as opposed to someone whose career involves gaining access to such information such as a journalist, cannot reasonably be expected to gain while still meeting private responsibilities. Disclosure requirements therefore force individual citizens to rely on private organizations, such as newspapers or advocacy groups, to find information that could directly affect the citizens' lives as well as their public reasoning ability. This is a political problem, not a technical problem. Some governments have been able to digitize important records for several years, such as the municipal government documents mentioned above. The difficulties of accessing information instead appear to be caused by governments' aversion to citizen oversight and the accompanying potential for criticism and embarrassment. Countering this built-in bias toward secrecy requires well-funded, knowledgeable and driven non-government actors, with resources greater than most individuals. Organized civil society groups therefore have an outsized role in meeting the public's need for information under this restrictive disclosure regime.

The government's spending power and ability to regulate civil servants' communications, unconstrained by constitutional rules, leaves citizens with uncertain access to expert knowledge. This applies to both physical and social-scientific knowledge. Environmental science provides the clearest example of the government's power over expert knowledge. The Harper government, closely connected to the oil industry, was both suspicious of 
environmental criticism as a potential threat to Canada's economic interests, and demonstrated a lack of interest in long-term research and development investment (Turner 2013). This manifested as cuts to environmental research groups within the government that were felt to implicitly criticize the government's oil export plans, most notably freshwater research and PEARL, which dispensed grants to scientists studying the effects of climate change (Turner 2013), as well as departmental restrictions on scientists' communications to the press (Turner 2013). The cuts diminished the governments' capacity to generate knowledge and give it to the citizenry; cuts to the Polar Environment Atmospheric Research Laboratory (PEARL), for instance, drove a star climate scientist to move from Canada to the United Kingdom, permanently weakening PEARL's research ability and public profile even after funding was restored (Turner 2013). These constraints on public understanding of science were instituted by the Harper government, but the mechanisms it used remain in place; the federal and provincial governments' spending power still renders scientific research and communication partially dependent on the ruling party's policy desires.

The limits of government-funded physical science, also apply to social science, as illustrated by the life and de facto death of the Parliamentary Budget Office. The Harper government formed the office to provide independent economic and fiscal forecasts to the Prime Minister and to Parliament, only to find itself in conflict with its founder for exercising its mandate. Two principle matters brought the PBO and the federal government into conflict after its creation: projected budget deficits and the expected cost of F-35 fighter jets. The dispute over the cost of the F-35 partially developed from methodology-government estimates used the average flyaway cost of the planes (the cost of the plane's construction, assessed at the 
moment it is delivered to the purchaser) while the PBO drew up an estimate of the plane's lifecycle cost (which included maintenance, replacement parts and upgrades as well as the initial purchase)- but the different methodologies also revealed differences in estimated total costs, supplying evidence that the government had underestimated the cost of the planes (Page 2013). A similar disagreement developed over budget projections, with the PBO measuring shortfalls in Canada's economic performance relative to an estimated maximum and inferring (correctly) from said estimates that the government's budget deficits for several years after the office's founding, would exceed official government estimates (Page 2013). This led to public disputes with the government over the validity of the PBO's estimates, with government ministers sent to press conferences to divert discussion away from and denounce the Office's conclusions (Page 2013). The conflict with the Prime Minister's Office led to a weakening of the PBO, with funding reduced and highly-trained staff leaving out of frustration (Page 2013). The same pressures brought to bear on the federal government's environmental scientists, were brought to bear in this case as well: control over funding and control over messaging, though in this case the government's ability to control messaging was partially compromised since the office was designed to operate at arm's length. The Public Budget Officer opined postresignation, that the Officer should be chosen by and answer to Parliament rather than the Prime Minister's Office (Page 2013), but even if this were implemented for this and similar arm's-length offices, party discipline would still allow the Prime Minister of a majority government to exercise control through both spending (or lack thereof), and through influence over Parliamentary discussion. These powers are part of the current structure of the 
government, not the unique product of Stephen Harper's personality. The temptation to control information will remain, to the detriment of public reason.

The government is only partially trustworthy in terms of teaching basic thinking skills and knowledge, because both thinking skills and knowledge can challenge an interested party's motivated errors in reasoning or cast doubt on a comprehensive doctrine, and therefore become a political liability for a government that relies on those groups. The most direct way a public education system can prepare students to be public reasoners, for instance, is to train citizens to recognize informal fallacies so that invalid arguments can be recognized and lose their power. Such education has to be universal since the same data can be used to support different fallacious arguments from any point of the political spectrum. Labelling someone a communist, for instance, may provide a convenient way to discredit a source of information in some political circles while unduly enhancing its credibility in others (Baillargeon 2008). Informal fallacies break down into discrete items, such as the appeal to authority, appeal to tradition, hasty over-generalizations and similar discrete invalid statements which can be individually identified by an alert listener (Foreman, Fosl and Watson 2017). Data manipulation poses a similar problem, but both speaker and listener are potentially limited by the resources they have to access data and the specialized skills needed to manipulate or evaluate statistics. Obvious misrepresentations can nonetheless be spotted by a layperson. Basic numeracy exercises such as estimating the number of bricks in a given building can give a layperson a sense of the relationship between quantities (useful for political questions such as the risk posed by terrorist attacks), while misuse of statistics includes crudely misleading visuals that can easily be spotted (Baillargeon 2008). These are all general skills. Learning to recognize 
informal fallacies or misuse of statistics does not commit anyone to a particular political ideology or religion or require exceptional knowledge or intelligence. These basic skills can nonetheless cast doubt on comprehensive doctrines, especially doctrines that prioritize intuition and unexamined experience like those examined above, and can therefore be difficult to teach. An extreme example happened in Texas: the state's proposed critical thinking curriculum provoked a unified counterattack from the state's political opposition and churches, which complained that critical thinking skills would undermine parental and scriptural authority by teaching students to examine these authorities (Waggoner 2012). This problem can develop even with general critical thinking education, but teaching that targets specific false beliefs can aggravate it. General critical thinking education does not appreciably reduce students' "epistemically unwarranted beliefs" (unproven and implausible things like UFOs, spirits, etc.). It has to both teach generally applicable skills and target specific unwarranted beliefs to noticeably improve students' ability to spot unreasonable claims (Dyer 2019). The most effective way to teach critical thinking skills, therefore requires the public education system, and by extension the government, to clearly reject and criticise beliefs which large groups of citizens may hold dear. This holds particular risks for the government because unwarranted beliefs often have to be targeted early in a person's life once they are capable of grasping both comprehensive doctrines and good reasoning. People committed to unwarranted beliefs can develop coherent but closed sets of beliefs around them and either assimilate criticisms into those systems without conceding the irrationality of their beliefs, or rejecting any evidence that does not already fit (Wilkins 2011). Comprehensive doctrines such as religions, likely to incorporate beliefs that cannot stand up to the realism that public reason requires, would 
therefore be likely targets for any such early intervention, which would then carry a high political cost.

The problem of limited and slanted information access, a major problem for a public reasoner, is the most difficult to correct because it originates in the structure of both government and media rather than from individual errors in reasoning. Filters on traditional "gatekeeper" media, for instance, can develop without any conscious long-term intervention on the part of policymakers or powerful interest groups, due to the constraints built into a profitdriven information system: reliance on cheap and easily accessible source, particularly government sources with an obvious interest in controlling information, the threat of civil penalties from private interests as well as government harassment, shared ideology amongst gatekeepers and reliance on advertising (which ties the success of information providers to the disposable income of their audience) (Chomsky and Herman 1988). Critical thinking can partially compensate for these limits by allowing citizens to recognize important omissions, but does not by itself give citizens the necessary information being omitted. The fallacy of withheld information is inherent difficult to defend against because it entails the fallacious reasoner withholding relevant information which they have but their listeners do not, and who may not be aware of their own ignorance (Baillargeon 2008). A solution for this problem would require the government to defy both its own immediate self-interest and that of influential private actors. The government is therefore unlikely to address the structural obstacles to public reason unless compelled to do so by outside pressure. Attention must therefore turn to the role of civil society in promoting and sustaining public reason. 


\section{2: the Role of Civil Society Groups.}

The problems mentioned above, stem partially from a mismatch between the information needs of the citizenry and the government's interests, as well as from the deficient reasoning of a large part of the citizenry. The educational gap can be filled by civil society groups, given sufficient funding and organization. Anybody who does not adhere to a popular and influential comprehensive doctrine has an obvious interest in maintaining a neutral public discourse conducted according to the principles of public reason, since to do otherwise would risk handing control of the state they live in to followers of a comprehensive doctrine antithetical to their own beliefs. This fact manifests as anxiety in the United States and a successful detachment of the Canadian government from any single comprehensive doctrine, accusations of Christian hegemony masquerading as liberalism notwithstanding. The partial overt dominance of Christianity in American politics has led to frustration amongst politicized Christians and fear amongst religious minorities, with the former far more likely to believe that religion's role in politics is unfairly restricted and the latter more likely to fear that the majority religion may dominate political life (Dick 2016). The Canadian and provincial governments, absent a dominant overt Christian presence in politics, have kept comprehensive religious doctrines out of power; Canada did not enact any discriminatory religious laws from 1990 to 2008, a time which saw increasing legal oppression of minority religions in Europe and the industrialised West in general (Fox 2012). Public reason has a natural constituency: everyone who would not benefit from the most powerful comprehensive doctrine in the country.

The fundamental characteristics of a publically unreasonable statement can be spotted by a non-expert citizen, and the basic knowledge and thinking skills needed to detect them do 
not require a large educational infrastructure run by the state. Fallacious reasoning and misused evidence are recognizable outward symptoms of doctrine that is publically unreasonable because it does not appeal to a shared reality. Appeals to faith in things not seen, whether to an immaterial and imperceptible being who lends unchallengeable authority to a sacred text, or to feeling and intuition as the ultimate test of a political position's justice, can be made obvious to citizens. Civil society groups representing those who do not benefit from antirealist doctrines, can point out specific cases of unwarranted belief without having to face the same political consequences as elected governments or otherwise worry about offending the people whose doctrines they criticize. The legal protections of liberal democracies give such groups the ability to organize and, when necessary, appropriate for themselves the benefits given to organizations that promote unreasonable doctrines. Politicized religion in the United States, for instance, has provoked greater organization and legal action from American atheists, and more forceful arguments from atheist publications to reflect their increasing confidence (Dick 2016). This shows a large, organized group of citizens pushing the rest of the country to accept the basic requirement of public reason. Atheists of otherwise differing political opinions were united not only by disbelief in the supernatural but also belief in the value of reason and science and the conviction that religion should be removed from politics (Dick 2016). Civil society groups explicitly devoted to public reason, independent of a specific political party or ideology, have a prototype in this case. 


\section{Conclusion.}

Public reason is an unavoidable feature of a polity with any meaningful degree of democratic government, and its epistemic rules are necessary in the absence of any single mind capable of grasping the totality of knowledge relevant to the use of state power (in other words, in the absence of an omniscient philosopher-king). It should therefore worry any reasonable observer of Canada that the country's citizens and ruling institutions are at best partially equipped to exercise and support public reason. The government has multiple incentives to avoid any serious attempt to prepare the citizenry for public reason. The institutions that promote comprehensive doctrines are no more likely to promote a form of thought that would discredit them. Civil society and individual citizens will therefore have to do most of the job themselves. 


\section{$\underline{\text { Reference List }}$}

Astourian, A.P. (2018), A New Defense of Public Reason, (PhD Dissertation) available at: https://search-proquest-com.ezproxy.lib.ryerson.ca/docview/2055697044?pq-

origsite=summon

Badgley, K., Dixon, M.J. \& Dozois, M. (2003), In Search of the Chill: Access to Information and Record-Keeping in the Government of Canada, Archivaria 55 (Spring 2003), 1-19, https://archivaria.ca/index.php/archivaria/issue/view/414

Badiola, C.B. (2018), Science as Public Reason: a Restatement, Res Publica, 24(4), 415-432, https://link-springer-com.ezproxy.lib.ryerson.ca/article/10.1007\%2Fs11158-018-09410-3

Baillargeon, Normand (2008), A short course in intellectual self-defense: Finding your inner Chomsky, New York, NY: Seven Stories Press

Boghossian, P. (2006), Fear of knowledge: Against relativism and constructionism, published online 2010 by Oxford Scholarship Online, available at: https://www-oxfordscholarshipcom.ezproxy.lib.ryerson.ca/view/10.1093/acprof:oso/9780199287185.001.0001/acprof$\underline{9780199287185 .}$.

Carrion, M.L. (2018), "You Need to Do Your Research": Vaccines, Contestable Science and Maternal Epistemology, Public Understanding of Science 27(3), 310-324, https://journals-scholarsportalinfo.ezproxy.lib.ryerson.ca/details/09636625/v27i0003/310 ntdyrvcsame.xml

Cohen, J. (2009) Truth and Public Reason, Philosophy and Public Affairs, 37(1), 2-42, https://wwwjstor-org.ezproxy.lib.ryerson.ca/stable/40212835?pq-

origsite=summon \&seq=1\#metadata info tab contents

Cote, J., Grayson, J. Paul et al. (2019), A Call to Action: Academic Skill Deficiencies in Four Ontario Universities

Council of Canadian Academies (2014), Science Culture: Where Canada Stands, published by Council of Canadian Academies, Ottawa, Ontario

Davies, A. \& Lithwick, D. (2010), Government 2.0 and Access to Information: 1. Recent Developments in Proactive Disclosure and Open Data in Canada, published by Legal and Legislative Affairs Division, Parliamentary Information and Research Service, Ottawa, Ontario

Dick, H. (2016), Challenging Christian Liberalism: Religious Minorities and the Public Sphere (PhD Dissertation), retrieved from: https://search-proquestcom.ezproxy.lib.ryerson.ca/docview/1812336606?pq-origsite=summon

Dyer, K. D., \& Hall, R. E. (2019). Effect of Critical Thinking Education on Epistemically Unwarranted Beliefs in College Students. Research in Higher Education, 60(3), 293-314, https://link-springer-com.ezproxy.lib.ryerson.ca/article/10.1007\%2Fs11162-018-9513-3 
Feldman, R. \& Warfield, T.A. (eds.) (2010), Disagreement, Oxford, United Kingdom: Oxford University Press

Fluss, H. \& Frim, L. (2019), Aliens, Antisemitism and Academia, Jacobin, retrieved from: https://www.jacobinmag.com/2017/03/jason-reza-jorjani-stony-brook-alt-right-arktoscontinental-philosophy-modernity-enlightenment/

Foresman, G. A., Fosl, P. S., \& Watson, J. C. (2016). The critical thinking toolkit. John Wiley \& Sons

Fox, J. (2012), The Last Bastion of Secularism? Government Religion Policy in Western Democracies, 1990 to 2008, Journal of Contemporary European Studies 20(2), 161-180, https://journals-scholarsportalinfo.ezproxy.lib.ryerson.ca/details/14782804/v20i0002/161 tlbosgiwd1t2.xml

Fultner, B. (ed.) (2011), Jurgen Habermas: Key concepts, Durham: Acumen Publishing Gidengill, E. \& Stolle, D. (2010), What do Women Really Know? A Gendered Analysis of Varieties of Political Knowledge, Perspectives on Politics 8(1). 93-109, https://journalsscholarsportalinfo.ezproxy.lib.ryerson.ca/details/15375927/v08i0001/93 wdwrkaaovopk.xml

Gin, W. (2012), Jesus Q. Politician: Religious Rhetoric in the United States, Australia and Canada, Politics and Religion 5(2), 317-342, https://search-proquestcom.ezproxy.lib.ryerson.ca/docview/2210973657?pq-origsite=summon

Goldenberg, M.J. (2015), Whose Social Values? Evaluating Canada's "Death of Evidence" Controversy, Canadian Journal of Philosophy 45(3), 404-424, https://journalsscholarsportal-info.ezproxy.lib.ryerson.ca/details/00455091/v45i0003/404 wsvecoec.xml

Goodyear-Grant, E., Scott, J.S. \& Hiebert, J. (2013), The Courts/Parliamentary Trade-Off: Canadian Attitudes on Judicial Influence in Public Policy, Commonwealth and Comparative Politics 51(3), 377-397, https://journals-scholarsportalinfo.ezproxy.lib.ryerson.ca/details/14662043/v51i0003/377 tctcaojiipp.xml

Harding, S. (1997), Comment of Hekman's “Truth and Method: Feminist Standpoint Theory Revisited": Whose Standpoint Needs the Regimes of Truth and Reality, Signs 22(2), 382-391, https://www-jstor-org.ezproxy.lib.ryerson.ca/stable/3175279?pqorigsite=summon \&seq=1\#metadata info tab contents

Hedrick, T. (2010), Rawls and Habermas: Reason, pluralism and the claims of political philosophy. Stanford, California: Stanford University Press

Hochschild, A. (2016), Strangers in their own land: Anger and mourning on the American Right. New York, NY: The New Press 
Hook, D. \& Rienstra, B., Weakening Habermas: the Undoing of Communicative Rationality, Politikon 33(3) (December 2006), pp. 313-339, https://journals-scholarsportalinfo.ezproxy.lib.ryerson.ca/details/02589346/v33i0003/313 whtuocr.xml

Jasanoff, S. \& Simmet, H.R. (2017), No Funeral Bells: Public Reason in a "Post-Truth" Age, Social Studies of Science, 47(5), 751-770, https://journals-scholarsportalinfo.ezproxy.lib.ryerson.ca/details/03063127/v47i0005/751 nfbpriaa.xml

Johnson, T.L. (2015), On the Limits of Rights and Representations: The Moral Challenge of Blackness and the Problem of Public Reason, Journal of Religious Ethics 43(4), 697-722, https://journalsscholarsportal-info.ezproxy.lib.ryerson.ca/details/03849694/v43i0004/697 otlorar.xml

Kappel, K. \& Jonch-Clausen, K. (2016), Scientific Facts and Methods in Public Reason, Res Publica, 22 (2), 117-133, https://link-springercom.ezproxy.lib.ryerson.ca/article/10.1007\%2Fs11158-015-9290-1

March, Andrew F. (2013), Rethinking Religious Reasons in Public Justification, American Political Science Review 107(3), 523-540, https://www-jstororg.ezproxy.lib.ryerson.ca/stable/43654922?pqorigsite=summon \&seq=1\#metadata info tab contents

Maynard, C. (2019), Failing to Strike the Right Balance for Transparency: Recommendations to Improve Bill C-58: An Act to Amend the Access to Information Act, Government of Canada, retrieved from: https://www.oic-ci.gc.ca/en/resources/reports-publications/failingstrike-right-balance-transparency

Milner, H. (2007), Political Knowledge and Participation Among Young Canadians and Americans, Montreal: Institute for Research in Public Policy

Moe, H. \& Ytre-Arne, B. (2018), Approximately Informed, Occasionally Monitorial? Reconsidering Normative Citizen Ideals, The International Journal of Press/Politics 23(2), 227-246, https://journalsscholarsportal-info.ezproxy.lib.ryerson.ca/details/19401612/v23i0002/227 aiomrnci.xml

Napier, J. (2015), Toward a Hermeneutic of Religion in the Public Sphere: Encouraging a Robust Public Discourse (PhD Dissertation), available at: https://search-proquestcom.ezproxy.lib.ryerson.ca/docview/1754628749/98F3AD7DE4CA451EPQ/2?accountid=13631

Newman, O. (2015), Liberalism in Practice: The Psychology and Pedagogy of Public Reason (PhD Dissertation), available at: http://cognet.mit.edu.ezproxy.lib.ryerson.ca/book/liberalism-practice

Nilsen, K. (1999), Public Access to Information in Canada in an Electronic Environment, Government Information in Canada 17, https://search-proquestcom.ezproxy.lib.ryerson.ca/docview/232076724?pq-origsite=summon

Page, K. (2015), Unaccountable: Truth and Lies on Parliament Hill, Toronto, Ontario: Penguin Canada

Polletta, F. \& Callahan, J. (2017), Deep Stories: Nostalgia Narratives, and Fake News: Storytelling in the Trump Era, American Journal of Cultural Sociology 5(3), 392-408, 
https://search-proquest-com.ezproxy.lib.ryerson.ca/docview/1954554907?pq-

origsite=summon

Rawls, J. (2005), Political Liberalism: Expanded Edition, New York: Columbia University Press

Rayside, D., Sabin, J. \& Thomas, P. (2017), Religion and Canadian Party Politics, Vancouver: UBC Press

Rosenbaum, S. (2009), Must Religion be a Conversation-Stopper? Harvard Theological Review 102(4), 393-409, https://journals-scholarsportalinfo.ezproxy.lib.ryerson.ca/details/00178160/v102i0004/393 mrbac.xml

Schwartzman, M. (2011), The Sincerity of Public Reason, The Journal of Political Philosophy 19(4), 375-398, https://journals-scholarsportal-

info.ezproxy.lib.ryerson.ca/details/09638016/v19i0004/375 tsopr.xml

Turner, C. (2013), The war on science: Muzzled scientists and willful blindness in Stephen Harper's Canada, Vancouver: Greystone Books Limited

Vallier, K. (2018), Exit, Voice and Public Reason, American Political Science Review 112 (4), 1120-1124, https://journals-scholarsportalinfo.ezproxy.lib.ryerson.ca/details/00030554/v112i0004/1120 evapr.xml

Watts, G. (2016), The personal politics of spirituality: On the lived relationship between contemporary spirituality and social justice among millenials (Master's Thesis), available at: https://search-proquest-com.ezproxy.lib.ryerson.ca/docview/1826410468?pqorigsite=summon

Wilkins, J.S. (2011), Are Creationists Rational?, Synthese 178(2), 207-218, https://linkspringer-com.ezproxy.lib.ryerson.ca/article/10.1007\%2Fs11229-009-9544-6

Zoffini, E. (2012), The Place of Comprehensive Doctrines in Political Liberalism: On Some Common Misgivings About the Subject and Function of the Overlapping Consensus, Res Publica 18(4), 351-366, https://link-springercom.ezproxy.lib.ryerson.ca/article/10.1007\%2Fs11158-012-9197-z

Zoonen, L. (2012), I-Pistemology: Changing Truth Claims in Popular and Political Culture, European Journal of Communication 27(1), 56-67, https://journals-scholarsportalinfo.ezproxy.lib.ryerson.ca/details/02673231/v27i0001/56 ictcipapc.xml 